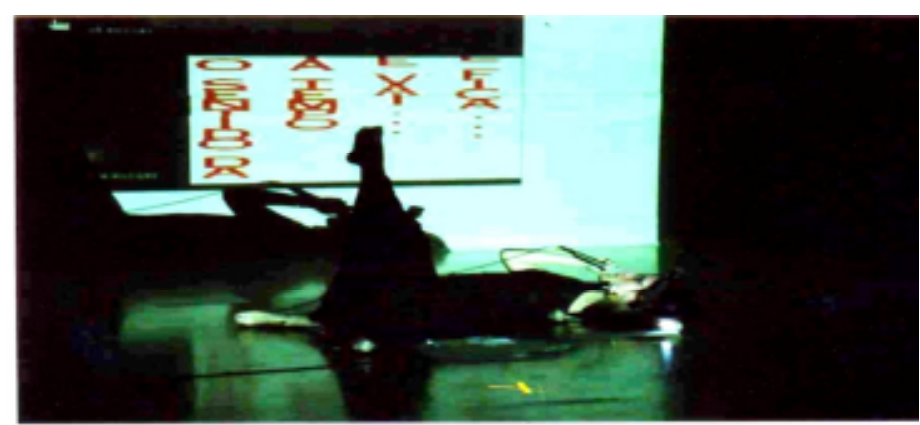

Brenda Marques Pena

\title{
10 anos de Poesia Digital Interativa no Brasil: a escritura expandida das poéticas intermidiáticas
}

\section{Wilton Azevedo \\ por Brenda Marques Pena(1)}

Wilton Luiz de Azevedo é Doutor-Senior em Comunicação e Semiótica pela Pontifícia Universidade Católica de São Paulo, Professor do Mestrado e Doutorado do Departamento de Literatura da Universidade Presbiteriana Mackenzie, faz Parte do Conselho Editorial de Hipermídia da Paris VIII e do coletivo de arte Transitoire Observable. É também Conselheiro da AIWS - Association of Image Words And Sound, com sede em Dublin, Irlanda. Wilton Azevedo participou do DVD Alitre do coletivo Laboratoire Observable da Universidade Paris VIII, lançado este ano no E-Poetry com o trabalho sonoro e visual "Quando assim termina o nunca", que consiste em vídeo-poemas interativos.

Em 1997, Wilton Azevedo e Philadelpho Menezes começaram a trabalhar juntos. A parceria deles foi pioneira na produção de poesia digital interativa no Brasil. Philadelpho faleceu um mês após completar 40 anos em um desastre de automóvel, em 2000, no dia em que Wilton Azevedo chegou de Nova York para os dois começarem o Projeto Interprosa. Desmotivado pela perda do amigo, Wilton Azevedo só retomou o trabalho em 2002.

Em fevereiro de 2007, Wilton Azevedo apresentou o Poemachine no oppenport: Sound, Performance and Languagerealizado em fevereiro de 2007, em Chicago. O conceito trabalhado é o de pensamento virtual, interativo. O som é eletroacústico, ou seja, a voz e o eletrônico são trabalhados na performance. O processo de construção do poema hipermídia foi coletivo: Rita Varlesi fez os vídeos. A convite do poeta, participei 
da performance e da produção da trilha com os poemas "Badalada Sonora" e "With Without John"(2) . Em maio de 2007, apresentamos o poema hipermídia Atamena abertura do E-Poetry, - mais importante festival de poesia digital do mundo, realizado em Paris, França (3) .

\section{Brenda Marques - Como foi sua parceria na produção de poesia sonora e hipermídia com Philadelpho Menezes? Como foi a seqüência dos trabalhos, após a perda dele?}

Wilton Azevedo - Quando eu conheci O Philadelpho Menezes, convidei-o para fazer um $\mathrm{CD}$-Rom de poesia intermídia. Unimos o trabalho dele sonoro ao meu com o computador. Na época, o Phila trabalhava o dado sonoro, mas de forma analógica, pois até então ele não tinha trabalhado com hipermídia. Ele já conhecia a poesia sonora, intersignos, mas não a hipermídia. Ele não sabia nada de software nem como funcionava a programação. Eu, como designer e poeta, tinha o conhecimento dos dois. Quando começamos a trabalhar juntos em 1997, mostrei ao Philadelpho as possibilidades do som digital. Foi a partir daí que começamos a trabalhar no Projeto Interpoesia, que foi lançado com o Manifesto Digital e está completando dez anos. Poucas pessoas trabalham com a poesia hipermídia no mundo, pois para fazê-la é preciso entender a evolução da poética dos códigos: som, imagem e palavra. Não adianta entender de software sem entender de poesia para fazer um poema em meio digital. O poema-processo está mais ligado aos conceitos de hipermídia do que à poesia concreta. Não é à toa que Philadelpho Menezes recuperou Vladimir Dias Pino e Álvares de Sá - porque ele sabia que o trabalho com o dado sonoro está mais próximo do poema-processo.

\section{Brenda Marques - Como o senhor trabalha o som em suas poesias? Alguns trabalhos seus estão disponíveis na rede?}

Wilton Azevedo - A Poesia Sonora hoje continua existindo naperformance. Ela tem sido usada muito também em peças teatrais. Faço minhas performances com voz, samplers e imagens em tempo real. Tenho me dedicado aos sons, mas venho trabalhando com sistemas interativos. Para trabalhar melhor o dado sonoro, decidi montar em 2002 o Underlab - um laboratório/estúdio de som. Disponibilizo os trabalhos do estúdio em dois sites: http://www.mackenzie.com.br/interacao/www2003/index.htm http://www.estudiounderlab.com. 
Brenda Marques - Os poetas brasileiros têm produzido bons trabalhos de poesia digital?

Wilton Azevedo - Meu trabalho poético é hipermídia. Hoje se faz muito trabalho no Brasil no suporte digital mas, na minha opinião, é de baixa qualidade. Pelo fato de os softwares serem muito semelhantes os conceitos são confundidos. Alguns trabalham interatividade, chamando de "realidade virtual", outros trabalham caves com softwares interativos e chamam de "imersão", outros trabalham com jogos com conceitos da realidade virtual e hipermídia. Ou seja, tem pouca gente trabalhando a E-poetry ou poesia digital com a interação do dado sonoro, com as imagens em uma escritura expandida. Tenho defendido a idéia de que a hipermídia trabalha com a escritura expandida. No último File realizado em São Paulo, no SESI, em 2005, publiquei um texto no catálogo do evento que trabalha esse conceito, resultado de um levantamento de vários anos.

Brenda Marques - Fale mais sobre o conceito de "escritura expandida". A época da poesia sonora que trabalha mais a multimídia que a hipermídia já passou?

Wilton Azevedo - Nós não vivemos mais no momento da Poesia Sonora. Ela foi um período importante de experimentação, mas hoje vivemos numa ambiência criada pela fusão tecnológica, uma escritura que se expande. Delimito três períodos distintos de escritura para a arte:

10) Período das escrituras matriciais - há cerca de 20 anos, podíamos falar de matriciais de linguagem e separar a retórica, a imagem e o som. Mas do Dadaísmo para frente os sistemas não são mais analógicos e por isso não podemos falar em matriciais de linguagem.

$\left.\mathbf{2}^{\circ}\right)$ Período das escrituras intermediárias - como exemplo, temos as experiências de partituras de John Cage, desenhadas para mostrar que o som leva a uma ilusão imagética. Nessa escritura, há intercessão entre as artes, mas sem perder as matrizes.

$\left.3^{\circ}\right)$ Período da escritura expandida - Estamos no período da escritura expandida, em que há o rompimento das matrizes e a perda dos sistemas matriciais. A Poesia Sonora hoje está fundida a outros códigos que geram signos em expansão. Hoje, ela não se prende a dados sonoros como nós conhecemos, desde o serialismo de Shöemberg ao eletroacústico do compositor alemão Stockhausen. Vivemos diante de uma escritura cada vez mais expandida, que está no nível da potencialidade apontada no livro do Haroldo de Campos $A$ arte no horizonte do provável. 
Ela não existe pronta e terminada como nos sistemas analógicos. Para entender o conceito de escritura expandida, podemos usar como exemplo softwares como o Direct MX e Java (programações C $++)$. Quando se programa som, imagem ou texto em um Direct MX para o software trabalha-se com a escritura no sentido apresentado por Roland Barthes - um corpo, uma entidade que permite o estabelecimento de relações gramaticais, de leis sígnicas - dá no mesmo inserir um dado sonoro, imagético ou textual. É a mesma coisa de uma caneta em contato com o papel. Como suporte, não importa se o risco é sonoro, textual ou imagético. A partir dessa escritura expandida, programada digitalmente, é possível começar a explorar os dados interativos desses trabalhos sonoros e imagéticos.

São Paulo, 30 de outubro de 2006.

\section{Notas}

[1] Essa entrevista foi concedida à jornalista Brenda Marques Pena (Mestre em Literatura e Outros Sistemas Semióticos, UFMG), em 30 de outubro de 2006 em São Paulo/SP.

[2] Esses poemas sonoros podem ser ouvidos no link: www.recantodasletras.com.br/autores/brenda

[3] Um trecho da apresentação intitulado E-Poetry 2007: Brazillian epoet setting fire to poems on stage encontra-se disponível no site www. youtube.com/watch?v=2fRFdy1U2jg\&mode=related\&search. Acesso em $30 / 07 / 2007$. 